\title{
Language as an Element of Identity: Language of National Minorities in the Educational Systems of Belarus, the Czech Republic, Poland, and Ukraine
}

\begin{abstract}
Life in a culturally diverse environment and being a national minority member causes the socialization of young people to occur in more than one language. Language is not only a medium of culture but also a core element of identity. This article discusses the implementation of the right of national minorities to education in their languages. In Belarus, the Czech Republic, Poland, and Ukraine, there are national minorities of autochthonous character, along with schools with the language of a particular minority as the teaching language. The most developed and numerous network of schools operating in the official school system is in the Czech Republic. In Belarus and Ukraine, the legal possibility of opening and running minority schools was introduced several years ago. Not without significance is the functioning of parish schools, Saturday-Sunday schools, national or ethnic clubs. Apart from family, school is the basic place of learning the minority language, an important element of national identity. At school, learners deepen their cultural competences, within their national, majority group and European culture.
\end{abstract}

\section{Keywords:}

national minorities, education, language, identity, Belarus, the Czech Republic, Poland, Ukraine

1 Faculty of Arts and Educational Science, University of Silesia in Katowice, Poland. E-MAIL: basiagra@wp.pl ORCID: 0000-0003-2558-0294

2 Institute of Pedagogy, Faculty of Social Sciences, University of Silesia in Katowice, Poland. E-MAIL: lukaszkwadrans@poczta.fm ORCID: 0000-0001-6102-2308 


\section{INTRODUCTION}

East-Central Europe is inhabited by people belonging to national minorities. Today, the term 'national minority' is understood as "a group of people which is smaller in number than the remaining part of the population in this state and whose members are its citizens but have ethnic, religious or language qualities distinguishing them from the rest of the population and are guided by the will to preserve their own culture, tradition, religion or language” (Łodziński, 2004, p. 3). However, it should be emphasized that this understanding has the nature of a political declaration. So far, there has not been accepted a definition of national minority that would rank as an international agreement and would be legally binding. What is highlighted in many works, both in international and internal national documents, is the importance of the awareness of the person who declares their wish to belong to a given national minority. This is so because minority is not created top-down but through individual declarations.

Poles as a national minority live in many countries south and east of the borders of Poland. The representatives of national minorities live in Poland as well: Belarusians, Czechs, Lithuanians, Germans, Armenians, Russians, Slovaks, Ukrainians, and Jews. As well as these, there are members of ethnic minorities: Karaims, Lemkos, Roma, and Tatars. The presence of people belonging to national minorities resulted from creations of and changes to borders after World War I and II. Ethnographic factors were not taken into account when new borders were created so those peoples who chose not to move changed their state allegiance.

The transformation of the political systems which has taken place in most of the countries in this part of Europe has led to the empowerment of national minorities, which by taking advantage of the recognised rights of their members can then promote their own cultures. Although the number of people belonging to national minorities has decreased, they are nevertheless more visible and more openly make use of their rights.

The aim of the research was to learn about selected elements of social functioning of members of national minorities living in Poland and the Polish national minority living in Belarus, the Czech Republic, and Ukraine. In particular, the issues of regulation of the right of national minorities to implement education in the minority language and organization of teaching in the minority language. The research issues also include the category of language as an element of identity, which will be indicated by the language in home contacts and the language of communication with teachers and peers. 
For further analysis, the situation of the Polish national minorities in Belarus, the Czech Republic and Ukraine has been chosen, as well as the situation of the national minorities living in Poland. The nationality structure in these countries is diverse. The data obtained in the national census carried out in Belarus in 2009 indicate that there are 26 national communities there.

In the nationality structure, Belarusians constituted $83.7 \%$ of the population, Russians $-11.4 \%$ and $8.3 \%$, Poles $-3.9 \%$ and $3.1 \%$, Ukrainians $-2.4 \%$ and $1.7 \%$, Jews $-0.3 \%$ and $0.1 \%$, and other nationalities $0.8 \%$ (Statistical Bulletins..., 2009).

In Ukraine, apart from Ukrainians (77.5\% of the whole population) and Russians (17.2\%), there are Belarusians (0.6\%), Moldovans (0.5\%), Crimean Tatars (0.5\%), Bulgarians (0.4\%), Hungarians (0.3\%), Romanians (0.3\%), Poles (0.3\%), Jews (0.2\%), Armenians (0.2\%), Greeks (0.2\%), Tatars (0.2\%), Roma (0.1\%), Germans (0.1\%), Gagauzes (0.1\%), and people of other nationalities (1.3\%) (http://2001. ukrcensus).

The national census in 2001 showed that the Czech Republic is inhabited by Slovaks (193,190 people $-1.89 \%$ of the total population), Poles (51,968 people $-0.51 \%$ ), Germans (39,106 people $-0.38 \%$ ), Ukrainians (22,112 people $-0.22 \%$ ), Hungarians $(14,672$ people $-0.14 \%)$, Roma (11,746 people $-0.11 \%)$, Russians (1,106 people - 0.01\%) (www.czso.cz/csu).

The representatives of nine national minorities live in Poland: Belarusians $(46,880)$, Czechs (3,447), Lithuanians (7,863), Germans (147,814), Armenians (3,623), Russians (13,046), Slovaks (3,240), Ukrainians (51,001), Jews (7,508), as well as members of four ethnic minorities: Karaims (346), Lemkos (10,531), Roma $(17,049)$, and Tatars $(1,916)$.

Ethnic diversity in these countries has necessitated the creation of legal guarantees for the members of national minorities. These are state legal acts, bilateral agreements, and international regulations. Besides the history of a particular minority and its cultural, social and economic condition, these guarantees provide the framework within which the national minorities function.

\section{THE RIGHT OF NATIONAL MINORITIES TO EDUCATION IN THE MINORITY LANGUAGE}

Representatives of national minorities in the countries in question can make use of their right to teaching and learning in their native language. The factors which affect how far these legal regulations are actually observed are to do with the political system of a state and the practical aspects of their implementation, especially those 
related to human rights and liberties, the degree of dependence on international standards, the nature of these standards, the effectiveness of the assumed control mechanisms and the mutual relations of nationality groups in a particular country (Białek, 2008, p. 302). In all three countries, the teaching of minority languages is most frequently initiated by representatives of minorities, minority organizations, religious communities, cultural institutions and local authorities.

In Belarus, the rights of minority members are regulated by documents of various ranks, such as the Constitution of 1994, the Act of the Republic of Belarus on National Minorities of the $11^{\text {th }}$ November 1992, the Act of the Republic of Belarus on Education of the $29^{\text {th }}$ October 1991, the Act on Languages, directives of the government, presidential decrees and the methodological-instructive document On the Organization of Education for Children Belonging to National Minorities in the Republic of Belarus issued by the Ministry of Education (Pismo metodycznoinstruktażowe..., 1998).

In the Czech Republic, the right to education for national minorities is ensured by the Constitution of 1992, the Act on the Rights of National Minority Members in the Czech Republic of the $10^{\text {th }}$ June 2001, the Act on Education in Kindergarten, Primary, Secondary and Higher Vocational School of 2004.

In Ukraine, the legal foundations of education for national minority members are specified by various documents as well: the Constitution of 1996, the Ukrainian Declaration on the Rights of Nationalities of 1991, Declaration of the State Sovereignty of Ukraine of 1990, the Act on National Minorities in Ukraine of the $25^{\text {th }}$ June 1992, the Act on Education of the $23^{\text {rd }}$ May 1991, the Act on Vocational Education of the $10^{\text {th }}$ February 1998, the Act on Secondary Education of the $13^{\text {th }}$ May 1999, the Act on Higher Education of the $17^{\text {th }}$ January 2002, the Act on Languages of the $22^{\text {nd }}$ October 1989.

In a similar way, the rights of people belonging to national minorities in Poland are written into the Constitution of the Republic of Poland of the $2^{\text {nd }}$ April 1997, the Act on National and Ethnic Minorities and the Regional Language of the $6^{\text {th }}$ January 2005.

What has been specified in bilateral agreements is the legal situation of the members of the Polish national minority in the countries concerned, especially the issues of education, learning the language, establishing and maintaining their own educational, cultural and religious institutions and associations. The implementation of the right to education in the Polish language in kindergartens and schools additionally has to take into account the fulfillment of the conditions specified in the separate regulations in each country. Bilateral regulations confirm mutual care for compatriots who are citizens of different countries. In these countries, 
there are schools with Polish as the teaching language and, reciprocally, in Poland, learners belonging to national minorities have the possibility to be educated in their native language.

\section{FORMS OF ORGANIZING EDUCATION IN AND OF THE MINORITY LANGUAGE}

The level of institutionalization of Polish social, also educational, life in the countries concerned varies significantly. In each of them, school education concerning the minority language functions within the educational system of the majority. Members of a particular minority can benefit from the right to such education as well as other people who declare such a wish. Thus, these are schools open to all. In Belarus and Ukraine, due to the small number of schools educating in Polish within the state system of education, other forms of teaching Polish are organized and conducted by Polish minority organizations and the Church. This is supposedly done in the hope that these forms will pave the way for future official activities.

In Belarus, there are only two schools with Polish as the teaching language, in Grodno (since 1996) and Vawkavysk (since 1999). Both are 12-year secondary schools. Final year learners take their matriculation (matura) exam in the Polish language enabling them to study at university in Poland. There are also classes in which education is conducted in two equally important languages: Russian or Belarusian and Polish. Such classes are run in Minsk and Brest (there are Polish classes 1-4). They represent the so-called bilingual model. 669 learners are educated in the Polish language. Apart from this, 134 schools offer Polish as an optional subject. In 2012-2013, 4,756 learners made use of this opportunity (Jak uczy się języka polskiego...). Quite different data concerning the number of learners educated in Polish (870) and learning Polish (over 11 thousand children and youth) are provided by Polish national organizations, such as the Polish School Motherland in Belarus (Polacy na Białorusi walczq o swoje szkoły..., 2017).

The law allows the possibility of teaching Polish in Belarusian schools. The 'only' requirement is parents' application in which they declare that they want their child to learn Polish. However, the authorities exert pressure on parents not to write applications and they marginalize learning Polish in the state system of education in all possible ways. Due to economic reasons, as the Belarusian side explains, it sometimes happens that classes educating in Polish and classes with Polish as a subject are closed down. The authorities also refuse to open new classes with Polish as the teaching language (Gawin, 2000, p. 195). Consequently, the initiative is taken over 
by non-government organizations, which open and run social schools and the Polish language clubs. This is made possible through financial support from Poland. Apart from the Belarusian educational system, teaching takes place in Sunday schools (also known as social schools) of the Association of Poles in Belarus and the Polish School Motherland. The classes take place in the evenings during the week and at weekends. As well as lessons of the Polish language, learners have lessons in Polish history and geography. In higher classes, the interested learners can have lessons in maths, chemistry, and biology in Polish (Grabowska, 2013, p. 68).

Polish school education in the Zaolzie region of the Czech Republic has had a long and praiseworthy tradition. However, Zaolzie schools have had to cope with difficulties and the resistance of people unfavourably inclined towards the Polish cause. In addition, they have been affected by the falling number of learners for over a decade, which has resulted in fewer schools. In the previous decades, the reasons for this could be found in "the structural transformations in the Czechoslovakian system of education (as the result of which some lower schools were closed down), in the incorporation of Polish settlements into larger administrative units following mining setbacks in the county of Karvina, in the lack of vocational schools with Polish as the teaching language, in the decreased social usefulness of the Polish language in the community, in hindered contacts with Poland, in the worsening economic situation in Poland in the 1980s, and in the insufficient opportunities for full public articulation of the problems of Polish schools” (Jasiński, 2002, p. 127).

In the Czech Republic, about $90 \%$ of the youth declaring Polish nationality are educated in kindergartens and schools with Polish as the teaching language (Grabowska \& Ogrodzka-Mazur, 2010, p. 186). In the school year 2017/2018, the network of the Polish educational system in Zaolzie consisted of 33 kindergartens (Statystyka przedszkoli...), 25 primary and 2 secondary schools (Statystyka szkół..., 2017). In September 2017, 2,300 learners started education in these institutions, including 1,337 kindergarten-age children. Within primary education, there are two types of schools: younger class schools (1-5) and full class schools (1-9). Most of them function as independent administrative-economic units.

Within the Ukrainian system of education, there are various forms of teaching Polish at all stages of education, from kindergarten to universities and in weekend schools, parish schools and various courses for children, youth and adults.

There are three kindergartens with Polish as the teaching language and four Polish kindergarten groups in three Ukrainian kindergartens in Lviv.

Apart from two already functioning Polish schools in Lviv (now both general education schools with 11 classes), new general education schools have been 
opened in Mostyska and in Horodok, as well as primary schools in Strzelczyska and Lanovychi. They were built and equipped by Poland. In six schools with Polish as the teaching language, there were 1,233 learners in total in the school year 2016/2017 (Szkoła Poczq̨tkowa..., 2017).

Thirteen schools function as bilingual schools with Polish classes. In classes 1-4, all subjects are conducted in Polish. In classes 5-11, the Polish language, history of Poland and geography of Poland are taught in Polish. Learners finish school with the Polish final exams (the so-called matura). There are also Polish classes in Ukrainian schools, e.g., in Dovbysh (in Volhynia), Khmelnytskyi, and Kamianets-Podilskyi.

Fourteen schools offer Polish as one of the compulsory languages (as the second or third foreign language). It is confirmed on a school certificate and the obtained mark is taken into consideration in a learner's promotion to the next class. Learners take exams in the Polish language at the end of their primary and secondary school. In the school year 2008-2009, 6,889 learners made use of this form of learning Polish. The most frequent and popular forms of learning Polish are weekend schools, run by Polish associations. Their learners are both young and adults. They are often situated in public schools, but classes are also held in the premises of associations, in clubs, and cultural centres. There are also church schools, conducted in parishes and monasteries (as well as religious education, the Polish language, literature, history, geography, music and culture is taught in Polish) (Grabowska, 2013, pp. 129-130).

It is the Czech Republic which has the most developed network with the highest number of Polish schools operating within the official school system. In Belarus and Ukraine, the legal possibility of opening and running minority schools was introduced several years ago but the needs of Polish minorities in these countries have not been fulfilled for various reasons. In Belarus, the authoritarian rule of Alexander Lukashenko does not respect earlier bilateral agreements with Poland and the Russification policy, the conflict of the Belarusian government with the Association of Poles in Belarus and the inner breakup within the Association do not enhance open articulation of the rights of the Polish national minority.

The legal situation in Ukraine is favourable towards the Polish national minority. However, the country has been building its own national identity for such a short period and has had many internal problems and financial difficulties. This is provided as a justification for the refusal to open and run new schools, as well as for limiting the number of Polish language classes.

As mentioned earlier, Poland is inhabited by many national and ethnic minorities. Most of them make use of the right to be educated in the native language. 
Details for the teaching of the languages of national and ethnic minorities and the regional language in Poland at particular educational stages in the school year 2016/2017 are as follows (SIO, 2016): Belarusian language (48 schools/3,072 learners), Hebrew language (10/427), Lithuanian language (18/622), Rusyn (Lemko) language (36/333), German language (754/51,198), Armenian language (3/86l), Slovak language (11/219), Russian language (2/59), Ukrainian language $(186 / 3,136)$, Kashubian language $(485 / 20,323)$.

What is not included in the data concerning learners belonging to national and ethnic minorities is the education of children belonging to the Roma ethnic minority. "Roma children attend school irregularly or do not attend it at all, which results from their parents' lack of appreciation of the role of education in their later life and from treating school as an organ of repression and threat to the Roma identity". The data given in the report Roma about Education of Their Children - the Case of Carpathian Gypsies, prepared by the Association of Roma in Poland for the Ministry of National Education, indicated a low rate of schooling of children from this ethnic group. The special character of the Roma group, their willingness to defend their own cultural heritage, the sense of community and the attachment to tradition enhance their isolation, which in a way is a kind of escape from assimilation. Since the late 1980s, the education of Roma children was organized in separate classes, which were aimed at overcoming educational-adaptive barriers and at preparing Roma children for education in integrated classes. "Roma classes" were an attempt at emergency aid, a temporary solution, which however did not constitute an effective alternative to integrated forms of education. In Poland in 2001-2003, the pilot government programme for the Roma community was implemented in the Lesser Poland (Małopolska) Voivodeship. Its goal was to improve the condition of education among the Roma through increasing the school graduation rate, better attendance and learning outcomes of Roma children and youth, and to make it easier for the Roma to continue education in secondary schools. The long-term overall goal was decreasing the number of unemployed and unskilled Roma, as well as counteracting the marginalization of this ethnic group. In the following years, the Roma in the whole country were included in the aid programme by implementing The Programme for the Roma Community in Poland in 2004-2013. It involved eight areas, of which education was given priority. Further areas were: citizenship, counteracting unemployment, health, financial status, security, culture and preserving the Roma ethnic identity, and knowledge concerning the Roma community. The greatest part of the budget was spent on school books and accessories for Roma learners, as well as on compensation classes, speech therapy, conducting interest clubs and therapeutic dayrooms. 
The education of Roma children in class 0 was also subsidized and supporting teachers or Roma education assistants were employed (after previous training for Roma assistants). Summer and winter camps were organized and psychologicalpedagogical support was offered for Roma children and their parents. Children had the opportunity to have school meals.

The Government in their Act of $7^{\text {th }}$ October 2014 approved the implementation of The Programme for Social Integration of the Roma Community in Poland in 2014-2020. The main aim of the programme is to increase the level of social integration of the Roma in Poland through educational activities (including cultural, historical and citizen education), professional activation, health care and a better housing situation, as well as through working out the mechanisms which would enable these goals to be achieved. Among the detailed goals in the field of education, the following were included: supporting and promoting early school education of Roma children; organizing additional compensation classes in the Polish language in schools and kindergartens, especially in the initial stage; providing Roma children with school accessories (mostly coursebooks); supporting these children's insurance and enforcing school attendance. What was not included there were the goals associated with maintaining and enhancing the sense of ethnic identity (Program integracji społeczności..., 2014, pp. 42-43).

\section{LANGUAGE AS AN ELEMENT OF IDENTITY}

People belonging to national minorities often function simultaneously in two cultural codes. Thus, as H. Tajfel writes, "people possess a whole repertoire of separate categorial belongings, the significance of which for the notion of Ego may vary” (Tajfel, 1972). A member of a national minority may belong to many minority and majority groups and acquires social experience in them, enriching in this way their complex social identity, and activating a given identity depends on a complex of situational and contextual factors. Current research results show that national minority members often manifest a multidimensional identity based on the regional identity (Grabowska, 2013). What is worth mentioning here is the definition of identity, suggested by Jerzy Nikitorowicz, who understands it as "a set of characteristic features of various quality, arranged in overlapping dimensions which complement each other and between which culture and education enter in the form of aerating roots (values, tradition, norms, law, customs, rituals, etc.) to affect and permeate all dimensions of identity, at the same time protecting their distinctiveness from shocks and conflicts and ensuring their unceasing existence 
and development” (Nikitorowicz, 2005, p. 83). Among other platforms of identity, the author mentions individual, family, local-parish, regional, national/state, continental and global identity. The awareness of their existence "results from the contact with another group, and is a way of describing oneself through belonging to social groups of various types” (Nikitorowicz, 1995, p. 70).

Building a multidimensional identity is enhanced through the knowledge of languages. Language fulfils many functions in human life. It is a tool for expressing needs (the instrumental function) as well as emotions and feelings (the personal function). Another function of language is associated with getting across thoughts and imaginations (the creative function), which constitutes the basic way of undertaking interpersonal contacts (the interactional function) and regulating them (the regulatory function). Finally, in the context of identity behaviours manifested in the field of school education, language is a tool for processing knowledge (the representational function) and it enables learning (the heuristic function) (Halliday, 1970). Language is also viewed as the core of culture and its medium at the same time (the national function). The culturalization of an individual happens through language. Parental encouragement of the mother tongue in turn will help the perception of the minority group as a distinct cultural community.

An indicator of national/ethnic identity is using one's minority language at home; a further indicator is recognizing the minority language as the native one. The language of the minority is often the first means of communication, not learnt but acquired in the family environment. The particular significance of language was indicated by Jerzy Smolicz in his "theory of indigenous values" (Smolicz, 1999, pp. 201-203). According to the author, each culture has a certain indigenous element which reflects its essence and, for the members of a particular community, indigenous elements constitute the centre of culture and function as identification and symbolic values. Life in a multicultural environment and being a national minority member causes the socialization of young people to take place in more than one language - even at home, children do not always communicate with parents in Polish. What also occurs is that the mother tongue is not the declared native language. The generation of middle aged Poles, especially those living in Belarus, often does not know Polish - what occurred there was a breakup in the continuity of transmission of Polish culture.

In 1999, in the Republic of Belarus, $16.5 \%$ of the total number of Poles declaring Polish nationality $(395,712)$ considered Polish as their native language, whereas ten years later, 294,549 people reported their Polish national identification and only 5.4\% declared that Polish was their native language. In 1999, 4.7\% used it in everyday situations but only 1.3\% did so in 2009 (Dworeckow, 2005, p. 93). The 1999 and 
2009 census data indicate a dramatic decrease in the number of people knowing the Polish language in the Polish minority group. Especially in Belarus, the command of Polish, largely owing to the Church, survived in the generation of grandparents. Although they did not learn it at school, their parents passed the knowledge of Polish down to them. However, the socialization concerning Polish in the generation of parents took place in very difficult conditions and breakups in the cross-generation transmission of language were frequent. Decades of Russification brought about the uprooting of the Polish language but also Belarusian. The majority of respondents communicate with their parents in Russian. It should be hoped that the Polish language will return to Polish families via the youngest generation.

According to the national census conducted in 2001 in Ukraine, there were 144,130 people declaring Polish nationality and for 19,195 (12.9\%) Poles, Polish remained their mother tongue. The majority of Poles (71\%) indicated the Ukrainian language as their mother tongue and $15.6 \%$ recognized Russian as such (http://2001.ukrcensus.gov.ua).

In Ukraine also, the Polish language is not widely used by the Polish national minority and the reasons for this are to be found in forced assimilation, Russification, and depriving minority members of their rights. Although there were two schools with Polish as the teaching language in Lviv after World War II, this did not satisfy the needs of Poles for learning their language.

Despite the intent of the Soviet authorities to denationalize Poles through Russification and atheisation, the Polish national minority is still large and in the 1990s its rebirth was observed. This has resulted in an increase in the number of people learning and knowing Polish.

As regards the Czech Republic, in 2011, out of the total number of people declaring Polish nationality (39,096), 75.2\% (33,597) indicated Polish as their mother tongue (https://www.czso.cz/..., p. 21). In Zaolzie, the language of common communication among the members of the Polish national minority is the dialect. Using it does not mean not knowing the literary Polish language. It is a manifestation of the love for the little homeland, a sign of patriotism. Knowing the dialect, also in the case of the youngest generation, can be interpreted as faithfulness to the regional culture. The successive generations of Poles in Zaolzie have lived in changing socio-political conditions and only the regional culture has been constant. Along with the dialect, it constitutes a certain fundamental context, on which the young build their feeling of identity. This feeling provides youth with security, especially in the world of liquid postmodernity.

In Belarus and Ukraine, not only children and youth learn the Polish language but also adults - they attend language courses organized by Polish national 
minority organizations. The development of ethnic education has led to a higher competence in Polish among young Poles.

For most of the surveyed learners from Ukraine, Polish is their native language but $27.9 \%$ declared two native languages. In Belarus, $86.8 \%$ of the learners declared Polish national identity and only slightly fewer (76.9\%) considered Polish their native language. In Zaolzie, only a half of the respondents declared that Polish is their native language and for $45 \%$ this role is fulfilled by the West Cieszyn dialect (Grabowska, 2013). The presented data allow for the observation that despite the decreasing number of people of Polish national identity, the number of people knowing Polish, using it and considering it as the native language is increasing.

In Poland, the data obtained in the 2011 national census indicate that people of other national identifications than Polish do not use Polish at home.

The population living in Poland in terms of national and ethnic identification and using the Polish or non-Polish language in 2011 was very diverse. For example, only $26 \%$ of Roma use only Polish, when among Jews it is over $90 \%$ of the population. Lithuanians use their mother tongue the most (over 45\%), Jews and Kashubians the least (just over 1\%) (Struktura narodowo-etniczna..., 2015, p. 78).

Among people belonging to national and ethnic minorities, only 26.6\% Roma use solely Polish in communication at home. Also the Roma most frequently use two languages to communicate with the closest family members (60.4\%). Thus, the Roma are an ethnic group for whom their own language commonly serves as the communication code. Lithuanians are a national minority which has strong bonds with their own language and over $45 \%$ of its members use only Lithuanian at home and just $17.5 \%$ use both languages. Jews (among whom $90.1 \%$ communicate with their families in Polish) and Russians (62.9\%) use their native language the least frequently.

The data presented in the census show that languages of national and ethnic minorities are used not only in family communication, but also in the case of the majority of Lithuanian minority members and over half of the representatives of the Ukrainian, Lemko and Roma minorities their first language is treated as native (Struktura narodowo-etniczna..., 2015, p. 78).

\section{NATIONAL SCHOOL AS A PLACE OF PRESERVING AND DEVELOPING THE SENSE OF NATIONAL/ETHNIC IDENTITY}

School educating in the minority language is aimed at protecting the group's culture and strengthening the national identity of its members. The purpose of 
a school with a minority language as the teaching one is manifested in the protection of the group's values and its culture. It aims to preserve and support national identity. However, a national school cannot become a prison of national culture or a shelter, it should be a centre promoting the culture of a national group in the local environment and, in the era of European and global integration, a meeting place for different cultures and the dialogue between them.

National schools play a crucial role in the life of a national minority. There during the educational process indigenous values such as language and culture are cultivated. Choosing a national school for a child is a manifestation of Polishness and an unequivocal declaration of belonging to the Polish national minority. Nevertheless, not all parents are able to send their children to these schools as there are few of them and they may be far away. These schools are often the most important institution where preserving the national culture and language is deliberately aimed at. This is particularly important in regard to learners coming from those families who do not take on the function of passing down the Polish culture and language.

Apart from family and media, school is an important, and for many learners essential, place for learning and communicating in the native language. The knowledge of languages, of the minority, of the majority and others, helps in daily functioning, but first of all it is a means of making contact with peers. At school, learners have a chance not only to deepen their cultural competences within the national culture but also to familiarize themselves with the culture of the majority. A significant element of school functioning is social interaction and the opportunity to meet people of different cultures, as learners often come from nationally and religiously mixed families. School curricula approved by state authorities introduce cultural pluralism and can develop a positive attitude towards the Other.

It is the Polish language which definitely dominates in school contacts (Grabowska, 2013, p. 391). It is not the only communication code, because students learn other languages and they communicate with their teachers in the respective language. Surveyed students declare this communication code with teachers as well as with peers. However, there occur other codes, probably those in which the youth communicate more freely. In Belarus, youth speak Russian most often, in Ukraine, Polish and Ukrainian, whereas in Zaolzie, the dialect dominates in peer contacts. As mentioned earlier, this is associated with a strong feeling of territorial identification. It should be noticed that the dialect has crept into learners' contacts with teachers, which is worrying as school should be a temple of the literary Polish language. Moreover, by making use of the eagerness to learn Polish, as Mirosław 
Sobecki notices, school should pass down also cultural contents associated with the non-language sphere so that the language becomes an instrument of participation in culture (Sobecki, 2003, p. 162).

\section{SUMMARY}

Language, understood as a social, cognitive, cultural and communication phenomenon, is regarded by Janusz Anusiewicz (1994) as an active factor which creates the human reality, specifying the limits and ways of exploring the world, and creating its image in the consciousness of the participants of a particular culture. This view is shared by Wojciech J. Burszta, who states that "language can be treated as a blueprint for the whole culture and its defining features can be generalized back into that culture" (Burszta, 1998, p. 63). This is the standpoint of the majority of those who research into the determining relationships between language and culture.

In all the countries selected for review, persons belonging to national minorities have the right to education in their mother tongue, but there is no unified form of education in the minority language and education of the minority language. The most institutionalized education in the minority language functions in the Czech Republic and Poland, and the least in Belarus. There, just like in Ukraine, the members of minorities themselves take care of the Polish language and on their initiative Polish language education is organized.

While discussing the points concerning the language of communication of people belonging to national minorities, it is important to point out the integrating function of language should be indicated - also its cultural, regional and dialect variations. These variations of the language of national minority communities are, on the one hand, culture-creating factors of these communities, and, on the other, a result of the clash of two competitive cultural systems, the cultural system of the minority's residence country and the culture of this minority.

Language plays an important role in the process of socialization. This process occurs through the use of language but, at the same time, its aim is equipping the individual with communication competences.

Being a tool/means of socialization, language helps an individual to become a competent member of a social group. Thus, language appears to be "a bridge facilitating communication with others, but also a factor of identification and an indigenous value which symbolizes the belonging of a person to this and not another culture” (Smolicz, 1997, p. 23). 
School, apart from family, constitutes the basic place of learning the language of a national minority. At school, learners deepen their cultural competences - within their national culture, the majority culture, as well as the European culture.

Translated by Agata Cienciała

\section{References}

Anusiewicz, J. (1994). Lingwistyka kulturowa. Zarys problematyki. Wrocław: Wydawnictwo Uniwersytetu Wrocławskiego.

Białek, T. (2008). Międzynarodowe standardy ochrony praw mniejszości narodowych i ich realizacja na przykładzie Białorusi, Litwy i Ukrainy. Warszawa: Scholar.

Burszta, W.J. (1998). Antropologia kultury. Tematy, teorie, interpretacje. Poznań: Zysk i S-ka.

Dworeckow, A. (2005). Sytuacja Polaków oraz problemy polskiej młodzieży na Białorusi. In: Z.J. Winnicki (Ed.), Polska mniejszość narodowa w Europie Środkowo-Wschodniej (pp. 93-98). Wrocław: Arboretum.

Gawin, F. (2000). Mniejszości narodowe na Grodzieńszczyźnie. Raport z monitoringu. Krasnogruda. Narody - Kultury - Małe Ojczyzny Europy Środkowo-Wschodniej, 12. Retrieved from: http://pogranicze.sejny.pl/krasnogruda_nr_12_feliks_gawin_mniejszosci_narodowe_na_grodzienszczyznie_raport_z_monitoringu,1311-1,12383.html.

Gąsior, G. (2008). Zaolzie. In: A. Knyt (Ed.), Zaolzie. Polsko-czeski spór o Śląsk Cieszyński 1918-2008 (pp. 2-3). Warszawa: Ośrodek KARTA.

Grabowska, B. (2013). Poczucie tożsamości młodzieży uczq̨cej się w szkołach z polskim językiem nauczania na Białorusi, Ukrainie i w Republice Czeskiej - studium porównawcze. Toruń: Adam Marszałek.

Grabowska, B., \& Ogrodzka-Mazur, E. (2010). Stan, problemy i perspektywy szkolnictwa z polskim językiem nauczania w Republice Czeskiej. In: T. Lewowicki, J. Nikitorowicz, \& A. Szczurek-Boruta (Eds.), Szkolnictwo z polskim językiem nauczania $w$ państwach europejskich - stan, problemy i perspektywy (pp. 185-233). Białystok-Cieszyn-Warszawa: Uniwersytet w Białymstoku, Uniwersytet Śląski w Katowicach, Wyższa Szkoła Pedagogiczna ZNP w Warszawie.

Halliday, M.A.K. (1970). Language Structure and Language Function. In: J. Lyons (Ed.), New Horizons in Linguistics (pp. 140-165). Harmondsworth: Penguin Books.

http://2001.ukrcensus.gov.ua/results/general/nationality/ (access date: 13.03.2018).

http://2001.ukrcensus.gov.ua/results/general/language/ (access date: 13.03.2018).

https://www.czso.cz/csu/2003edicniplan.nsf/t/C2003127AF/\$File/41140312.pdf (access date: 24.02.2018).

https://www.czso.cz/csu/czso/narodnostni-strukura-obyvatel-2011-aqkd3cosup\# (access date: 13.03.2018).

Jak uczy się języka polskiego na Białorusi. Liczby i fakty. Retrieved from: http://poland.mfa. gov.by/pl/embassy/news/f5026a6dfa11ae10.html (access date: 4.02.2018).

Jasiński, Z. (2002). Wybrane problemy szkolnictwa polskiego na Zaolziu i Kresach Ostrawskich w latach 1920-2000. In: J. Szymeczek (Ed.), Polacy na Zaolziu, 1920-2000. Zbiór referatów z konferencji naukowej, która odbyła się 13.-14.10.2000 w Czeskim Cieszynie (pp. 115-128). Czeski Cieszyn: Kongres Polaków w Republice Czeskiej. 
Łodziński, S. (2004). Międzynarodowe standardy ochrony i wspierania mniejszości narodowych. Instytucje oraz organizacje powołane do ochrony mniejszości. Warszawa: Kancelaria Sejmu, Biuro Studiów i Ekspertyz.

Misiejuk, D. (2002). Theoretical Assumptions of the "Nova” Educational Program. In: E. Czykwin, \& D. Misiejuk, Dwujęzyczność i dwukulturowość w perspektywie psychopedagogicznej. Białystok: Trans Humana.

Nikitorowicz, J. (1995). Pogranicze, tożsamość, edukacja międzykulturowa. Białystok: Trans Humana.

Nikitorowicz, J. (2005). Kreowanie tożsamości dziecka. Wyzwania edukacji międzykulturowej. Gdańsk: Gdańskie Wydawnictwo Psychologiczne.

Oświata i wychowanie w roku szkolnym 2016/2017 (2017, October 31). Warszawa, GUS. Retrieved from: https://stat.gov.pl/obszary-tematyczne/edukacja/edukacja/oswiata-i-wychowanie-w-roku-szkolnym-20162017,1,12.html (access date: 2.04.2018).

Pismo metodyczno-instruktażowe O organizacji w Republice Białoruś nauczania dzieci należących do mniejszości narodowych. Ministerstwo Edukacji RB do departamentów edukacji mińskiego i obwodowych komitetów wykonawczych, 10 March 1998, No. 06-13/172. Retrieved from: http://www.wspolnota-polska.org.pl/index.php?id=b_uw11 (access date: 2.03.2018).

Polacy na Białorusi walczq o swoje szkoły. (2017, April 25). Retrieved from: http://www.wilnoteka.lt/artykul/polacy-na-bialorusi-walcza-o-swoje-szkoly (access date: 4.03.2018).

Program integracji społeczności romskiej w Polsce na lata 2014-2020 (2014). Annex to Resolution No. 202/2014 of the Council of Ministers of 7 October 2014. Warszawa. Retrieved from: http://mniejszosci.narodowe.mswia.gov.pl/mne/romowie/program-integracji-spol/ 8303,Program-integracji-spolecznosci-Roma-in-Poland-for-years-2014-2020.html (access date: 4.03.2018).

Program na rzecz społeczności romskiej w Polsce na lata 2004-2013 (2003). Retrieved from: http://mniejszosci.narodowe.mswia.gov.pl/mne/romowie/program-na-rzecz-spole/program-na-rzecz-spole/tresc-programu-na-rzec/6670,Tresc-Programu.html (access date: 28.02.2018).

SIO (2016, September 30). System Informacji Oświatowej. Retrieved from: https://cie.men. gov.pl/sio-strona-glowna/dane-statystyczne/jezyki-obce-dane-statystyczne/ (access date: 2.04.2018).

Smolicz, J.J. (1997). Język - przeszkoda czy pomost? Język i edukacja w Australii. Studia Pedagogiczne, 62, pp. 19-27.

Smolicz, J.J. (1999). Współkultury Australii. Warszawa: Oficyna Naukowa.

Sobecki, M. (2003). Literatura jako wartość w identyfikacji narodowej reprezentantów mniejszości polskiej na Bialorusi - studentów pedagogiki na Uniwersytecie w Białymstoku. In: T. Lewowicki, E. Ogrodzka-Mazur, \& A. Gajdzica (Eds.), Świat wartości i edukacja międzykulturowa (pp. 153-163). Cieszyn-Warszawa: Uniwersytet Śląski - Filia w Cieszynie, WSP ZNP.

Statistical Bulletins of the 2009 Census: National Statistical Committee of the Republic of Belarus (2009). Retrieved from: http://belstat.gov.by/homep/ru/perepic/2009/itogi1.php (access date: 12.03.2011).

Statystyka przedszkoli. Rok szkolny 2017/2018. Retrieved from: http://www.pctesin.cz/files/ download/530-statystyka-przedszkoli-2017-2018.pdf (access date: 24.02.2018). 
Statystyka szkół podstawowych i średnich. Rok szkolny 2017/2018 (2017, September 13). Retrieved from: http://www.pctesin.cz/files/download/506-statystyka-sp-i-ss-2017-18.pdf (access date: 24.02.2018).

Struktura narodowo-etniczna, językowa i wyznaniowa ludności Polski. Narodowy Spis Powszechny Ludności i Mieszkań 2011 (2015). Warszawa: GUS. Retrieved from: https:// stat.gov.pl/files/gfx/portalinformacyjny/pl/defaultaktualnosci/5670/22/1/1/struktura_ narodowo-etniczna.pdf (access date: 14.02.2018).

Szkoła Poczqtkowa w Łanowicach (2017, March 22). Retrieved from: https://wid.org.pl/szkolapoczatkowa-w-lanowicach/ (access date: 24.02.2018).

Tajfel, H. (1972). La categorisation sociale. In: S. Moscovici (Ed.), Introduction à la psychologie sociale (pp. 385-426). Paris: Larousse. Cit.: A. Kwiatkowska, (1999). Tożsamość a społeczne kategoryzacje. Warszawa: Wydawnictwo Instytutu Psychologii PAN.

The Act on the Rights of Members of National Minorities in the Czech Republic of 10 July 2001. Zákon č. 273/2001. Retrieved from: http://www.zakony.cz/zakony/2001/251/zakon273-2001-Sb-zakon-o-pravech-prislusniku-narodnostnich-mensin-ao-zmene-nekterychzacon-SB2001273 (access date: 3.03.2018).

Ziaziun, I. (2001). Mniejszości narodowe Ukrainy - wykształcenie, kultura, status. In: Z. Jasiński, \& T. Lewowicki (Eds.), Oświata etniczna w Europie Środkowej (pp. 271-283). Opole-Warszawa: Instytut Nauk Pedagogicznych Uniwersytetu Opolskiego, Wyższa Szkoła Zarządzania i Administracji w Opolu, Wyższa Szkoła Pedagogiczna ZNP w Warszawie. 